\title{
REPRODUCTIVE BIOLOGY OF THE MUDSKIPPER Boleophthalmus boddarti IN SOC TRANG
}

\author{
Dinh Minh Quang ${ }^{1 *}$, Nguyen Thi Tra Giang ${ }^{1}$, Nguyen Thi Kieu Tien ${ }^{2}$ \\ ${ }^{1}$ Can Tho University, *dmquang@ ctu.edu.vn \\ ${ }^{2}$ An Khanh High School
}

\begin{abstract}
The mudskipper Boleophthalmus boddarti is an amphibious fish widely distributed in the mudflat regions in Asia, but its reproductive biology was poorly stydied. This study was conducted in the Tran De, Soc Trang, Vietnam, from March 2013 to February 2014, to investigate reproductive parameters of $B$. boddarti. Data analysis based on a total of 360 collected fish (188 females and 172 males) suggest that the sex ratio of this mudskipper was not significantly different between dry and wet seasons. This fish was a multiple reproducer and spawned in the wet season with a peak spawning in three main months of this season (August to October) as difference stages of oocytes were observed in the ovaries. The male $B$. boddarti released sperms during the reproductive season since different type of spermatogonia were found in stage $\mathrm{V}$ testis sections. This fish reached $11.52 \mathrm{~cm}$ total length at first sex maturation and was high fecundity $(9,800-$ 33,800 eggs), indicating a possible adaptation of this species to the monsoonal climate. The understanding of the reproductive biology of $B$. boddarti provides useful knowledge of its reproductive adaptation to the mudflat toward sustainable management in the study region.
\end{abstract}

Keywords: Boleophthalmus boddarti, fecundity, length at first maturity, mudskipper, spawning.

\section{INTRODUCTION}

Knowing of fish reproductive biology is useful for fishery management $[15,22]$. Fecundity is related to egg size and used to estimate fish recruitment and abundance [16], and information on the fish length at first maturity is helpful for fish stock management $[11,36]$. However, information on the reproductive biology of fishes, especially gobies, in the Mekong Delta, where fish stocks have been subjected to overexploitation [24], is limited.

The sympatric mudskipper Boleophthalmus boddarti (Pallas, 1770) is an elongated fish [23] and widely distributed in the Indo-Pacific regions including India, Thailand, China, Indonesia, Malacca, Myanmar, Guam and Vietnam [10, 29]. This gobiid species mainly occurs in the inter-tidal mudflat areas during ebb tide $[25,35]$. The $B$. boddarti is a distinct residential fish who builds the burrows for refuging from predator and feeding in the soft bottom patterns [7, 8, 28].

Although the Boddart's goggle-eyed goby Boleophthalmus boddarti (Pallas, 1770) is a commercial fish in some Asian countries [13,
26] and has a wide range of salinity from marine to freshwater [32], its information has been limited to external morphology [10] and living habitat $[8,28]$. This gobiid species shows isometric growth [26] and feeds mainly on diatom [30]. The fecundity of this goby vary with geographic location and is affected by environmental factors (e.g., pollution), and its ovary development is reported in Bhayandar, Kalyan and Vasai creeks around Mumbai regions [6]. However, the testis development, spawning period, and size at first mature of this fish has been limited. Although this gobiid species is a commercially important fish in Vietnam [26], the understanding on its reproductive biology has been unknown. Therefore, this study aims to understand reproductive biological characteristics including spawning pattern and season, size at first mature and fecundity of this fish that provides useful information for future sustainable exploitation and conservation this gobiid species in the present study area.

\section{MATERIALS AND METHODS}

Study sites and sampling 
This study was conducted for a year, from March 2013 to February 2014, in Tran De district, Soc Trang province, Vietnam. Deep gill nets with $1.5 \mathrm{~cm}$ mesh aperture in the cod end were set at the highest tide and retrieved after 23 hours during ebb tide along the margin of mangrove forest areas to collect monthly fish specimens in the study site $\left(9^{\circ} 28^{\prime} 47.41^{\prime \prime} \mathrm{N}\right.$, $\left.106^{\circ} 12^{\prime} 25.96^{\prime \prime} \mathrm{E}\right)$. After being sexed using external morphology of genital papilla, which was oval for female and triangle for male [27], fish specimens were measured total length (TL, nearest $0.1 \mathrm{~cm})$ and body weight $(\mathrm{W}$, nearest $0.01 \mathrm{~g})$. Fish specimens were identified based on their external description and classification [39] before being stored in 5\% formalin and transported to the laboratory.

\section{Gonadal maturity stage classification}

Ovaries and testes, in the laboratory, were removed from fish specimens and visually classified into six maturation stages according to the criteria on the black goby Gobius niger described by Vesey \& Langford (1985) [37]. The ovaries and testes were examined histologically as a biological indicator for oocyte development patterns using the staining procedure of Carleton et al. (1980) [5].

\section{Length at first maturity and fecundity determination}

The length at first maturity $\left(\mathrm{L}_{\mathrm{m}}\right)$ is the length at which $50 \%$ of the population is sexually mature [14]. This threshold was determined using the simple logistic curve equation $\mathrm{P}=1 /\left(1+\exp \left[-\mathrm{r} \times\left(\mathrm{TL}-\mathrm{L}_{\mathrm{m}}\right)\right]\right)$, where, $\mathrm{P}$ is the proportion of mature individuals in a length class; $\mathrm{L}_{\mathrm{m}}$ is the length with $50 \%$ of fish reaching sexual maturity, and $\mathrm{r}$ is a model parameter [40]. Thirty mature (stage IV) and ripe (stage V) ovaries were placed in the Gilson fluid for seven days to release oocytes [2], that were then counted in a petri dish to determine the batch fecundity of this mudskipper.

\section{Data analyses}

The positive relationships between fecundity and fish length and weight were estimated using logarithmic regression [21]. The difference in sex ratio between wet and dry seasons was examined using the $\chi^{2}$ test. The SPSS software v.21 was used for data analysis, and the alpha value in all tests was set at 0.05 or less.

\section{RESULTS AND DISCUSSION}

\section{Sex ratio}

A total of 360 individuals (188 females and 172 males) were collected at the study site during the period of study. Data analysis showed that the female to male ratio of $B$. boddarti was 1.0:0.9 in total, 1.0:0.8 in wet season and 1.0:1.1 in dry season, respectively, but the sex ratio of this fish was not significantly different from the ratio of $1: 1\left(\chi^{2}\right.$, $P>0.05$ in all cases). The sex ratio of $B$. boddarti was similar to that of Pseudapocryptes elongatus collected from the same region reported by Dinh (2008) [9]. In other gobies, sex ratios are deviated from 1:1. For example, more females than males Gobius vittatus are caught in the spawning season, as males $G$. vittatus guard their nests [17]. Silva \& Gordo (1997) [33] indicate that the cryptobenthic behavior of male Gobius niger results in more female being caught during the spawning season. Moreover, the $1: 1$ sex ratio of $B$. boddarti and $P$. elongatus may indicate that these gobies shared the same reproductive behavior.

\section{Ovary and testis development}

Ovaries: Stage I ovaries were too small, elongated and paired with a smooth surface. The ovarian sections composed of germ cell (GC) and oogonia (PO, fig. 1a). The diameter of ovaries increased to roughly $1 \mathrm{~mm}$ in stage II that were connected by connective tissues and covered by the rough surface with prominent blood vessels. The ovarian sections contained germ cells (SC), oogonia (PO) and some primary and secondary vitellogenic oocytes (PVO, SVO, fig. 1b). Stage III ovaries were larger compared to stage II, separated and became transparent with visible orange-yellow translucent eggs. Ovaries were covered with prominent blood vessels. Mature oocytes showed migratory nucleus toward the center and contained more yolk accumulation (e.g., secondary vitellogenic oocytes, SVO) and fewer oogonia (PO) in the ovarian sections (fig. 1c). 
At stage IV, ovaries contained small whitish eggs at the posterior end, and blood vessels were still prominent and eggs were extrudable with slight pressure on the abdomen. The ovarian sections mainly consisted of post vitellogenic oocytes (PsVO) with the nucleoli in the center of the nucleus and a few oogonia (PO), primary and secondary vitellogenic oocytes (fig. 1d). The ovaries reached the largest diameter at stage $\mathrm{V}$, became opaque and were covered by a firm membrane, containing mainly hydrated oocytes. The post vitellogenic oocytes were absent, but oogonia (PO) were scattered between primary and secondary vitellogenic oocytes (PVO, SVO) and hydrated mature oocytes (e.g., eggs, HMO, fig. 1e). No fish with stage VI of ovaries were found in this study (figs. 1, 2a).
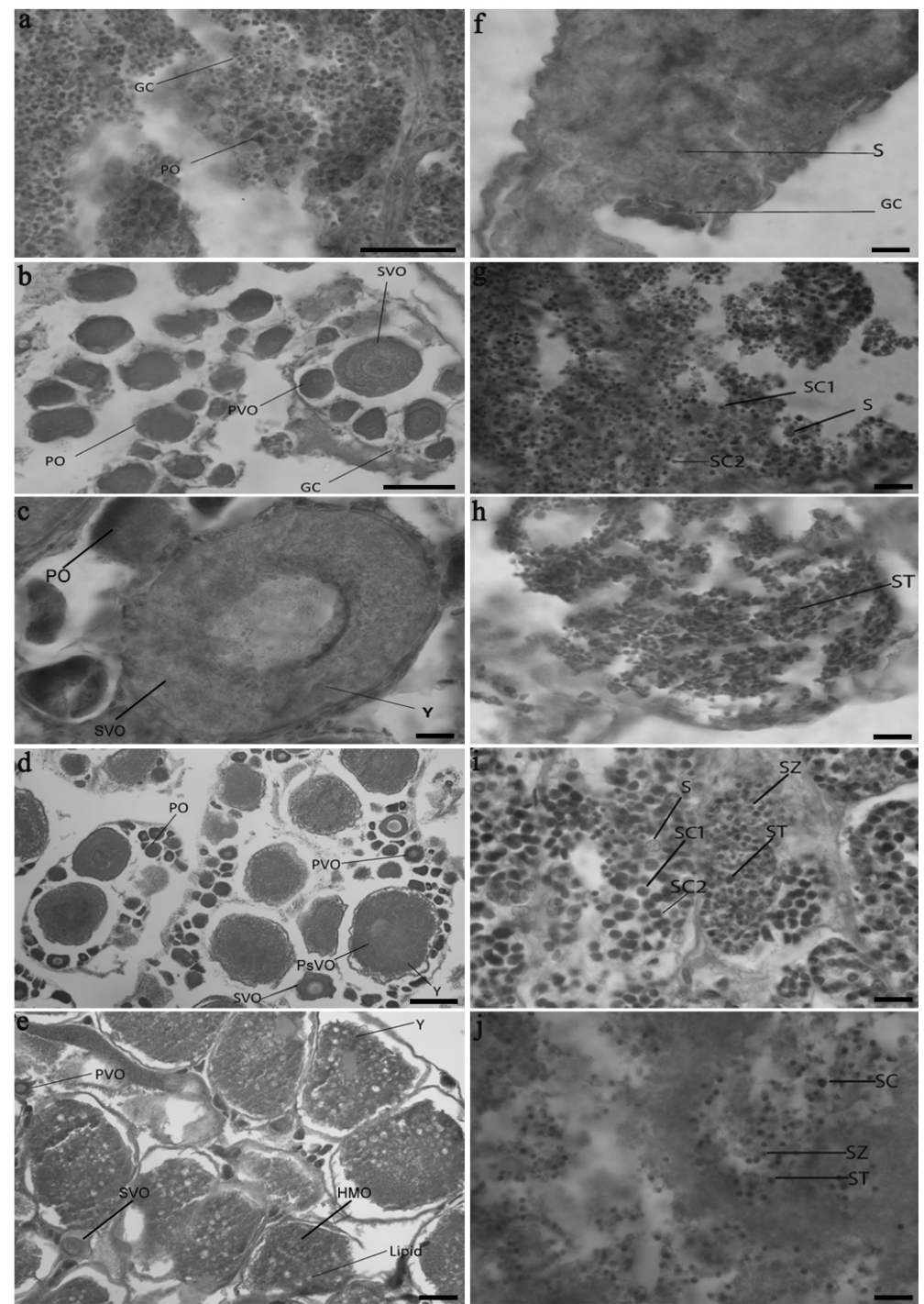

Figure 1. Gonad cross-section of B. boddarti

a-e: stage I-V of ovary; f-j: stage I-V of testis; GC: germ cell, PO: oogonia, PVO: primary vitellogenic oocytes, SVO: secondary vitellogenic oocytes, PsVO: post vitellogenic oocytes, Y: yolk, HMO: hydrated mature oocyte, S: Spermatogonia, SC1: primary spermatocytes, SC2: secondary spermatocytes, ST: spermatid and SZ: spermatozoa; scale bar: $200 \mu \mathrm{m}$. 
Testes: Stage I testes were too small, elongated and connected by connective tissue with a smooth surface, and were not easy to differentiate from the ovaries. There were many spermatogonia (S) and germ cells (GC) appeared in the testis sections (fig. 1f). Stage II testes were pale with a rough surface and about $1 \mathrm{~mm}$ in width. Many primary and secondary spermatocytes (SC1 and $\mathrm{SC} 2$ ) and a few spermatogonia (S) appeared in testis sections (fig. 1g). Testes became white, separate and translucent in stage III. The testis sections consisted of mainly primary and secondary spermatocytes ( $\mathrm{SC} 1$ and $\mathrm{SC} 2$ ), a few spermatids
(ST) and spermatozoa (SZ) in the sperm ducts (Fig. 1h). Stage IV testes were milky in color and swollen with a few blood vessels on the rough surface. The testis sections comprised many spermatozoa (SZ) and a few spermatids, primary and secondary spermatocytes in the sperm ducts (fig. 1i). Stage V testes reached the largest size with milky color. The testis sections contained mainly spermatozoa (SZ), a few primary spermatocytes (SC1), secondary spermatocytes (SC2) and spermatid (ST, fig. 1j). Similar to ovaries, fish with stage VI testes were not found in the present study (figs. $1,2 b)$.
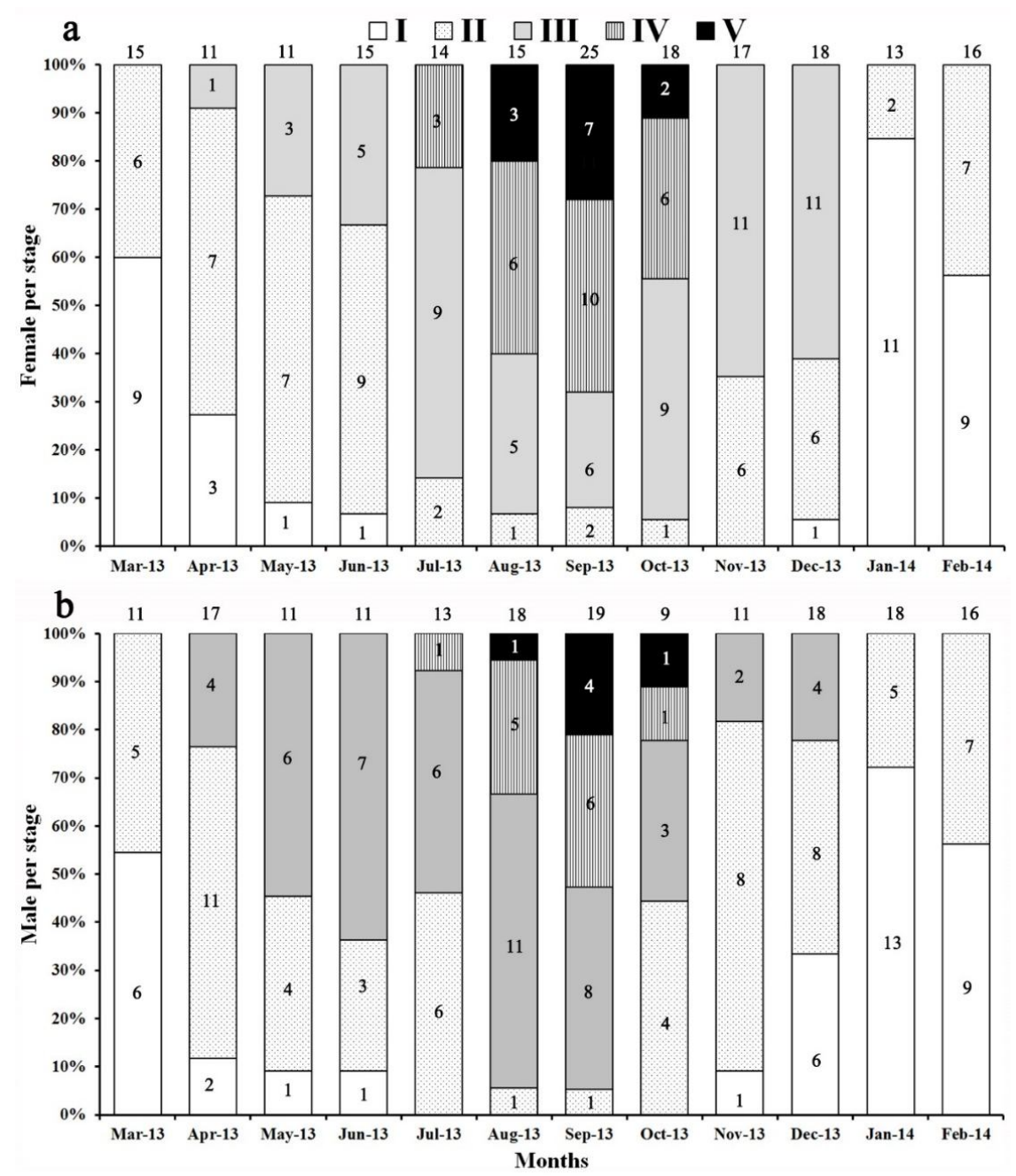

Figure 2. Gonadal stage compositions of female (a) and male (b) of B. boddarti (number on the top: total fish collected; number within a column: fish at each gonad development stage) 
In four months (July to October), the ovary developed from stage I and II to stage V. Most females with stage $V$ ovaries were found in late September (fig. 2a). Testis development shared a similar pattern with ovaries (fig. 2b). The oogonia and primary oocyte were found in all stages of ovaries. The sympatric mudskipper $B$. boddarti in the present study was a multiple batch spawner, supported by the coexistence of four oocyte types (oogonia, primary and secondary vitellogenic and hydrated mature oocytes) in the stage $\mathrm{V}$ ovaries. Moreover, different types of spermatogonia (primary spermatocytes, secondary spermatocytes, spermatid, and spermatocyte) were found in ripe testes (stage V), suggesting that male $B$. boddarti can release sperm several times during the reproductive season. This assumption was similar to most gobies that are serial spawners shedding eggs more than once through a spawning season rather than giving a single spurt of egg release [18].

Immature (stage I) and maturing ovaries (stage II) were found throughout the study, while early matured ovaries (stage III) appeared from the late dry to the end of wet season (April to December, fig. 2a). The mature and ripe ovaries appeared mostly in the wet season, whereas the ripe ovaries were mainly found in the mid-wet season (August to October). Similarly, the testis development showed the same as ovaries (fig. $2 b$ ). This pattern suggests that $B$. boddarti was a multi-spawner releasing eggs during a period of three months (August to October) with high precipitation, being similar to some fishes in the Mekong Delta as Pseudapocryptes elongatus [9].

\section{Length at first maturation and fecundity}

The length at sexual maturity $\left(L_{m}\right)$ was estimated from the maturity curve, and $50 \% \mathrm{~B}$. boddarti reached sexual maturity at $11.52 \mathrm{~cm}$ (fig. 3). The size at first sexual maturation is influenced by the biotic factors such as parental care [1], e.g., male Pomatoschistus marmoratus reaches first maturation at larger size compared to females due to parental care [20]. Additionally, length at first maturity of fish depends on environmental factors (location)
[38], e.g., P. marmoratus reaches $2.4 \mathrm{~cm}$ in TL at Suez Canal [12] but $2.7 \mathrm{~cm}$ in Mauguio Lagoonare [3]. The size at first mature of $B$. boddarti was strongly shorter than that of cooccurring goby $P$. elongatus $(15.4 \mathrm{~cm}$ for females and 16.3 for males) [9].

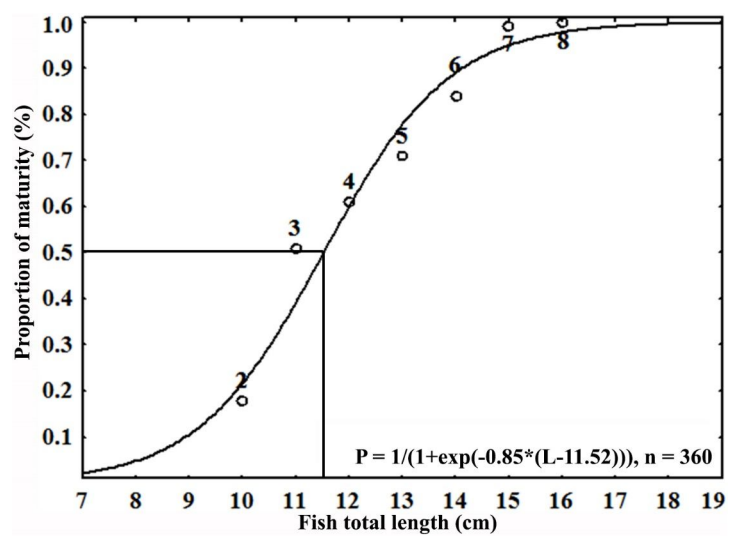

Figure 3. Length at first mature of B. boddarti

The female goby was a multiple spawner and a large fish released more eggs at each spawning event as the fecundity had a positive relationship with total length (Fig. 4a) and body weight (fig. 4b). Most gobies are repetitive spawners, and the fecundity and egg size depend on fish size $[17,22]$. Similarly, the present study revealed that $B$. boddarti was a serial spawner, and its fecundity positively related to fish size. Abundance and geographic location also cause the variation of fish fecundity [38], e.g. the difference in fecundity of $B$. boddarti among three creeks in Mumbai, India [6]. The B. boddarti fecundity in the previous study is 2,100-12,300 eggs and lower than that in the present study $(9,800-33,800$ eggs) as a consequence of the polluted environment in these creeks in Mumbai, India [6]. The batch fecundity of B. boddarti in this study is higher than that of Neogobius melanostomus (84 to 606 eggs) the upper Detroit River in North America [19] and Crystallogobius linearis (200-700 eggs) in the coastal central area of the Adriatic Sea [4], but lower than Valenciennea strigata (60,000160,000 eggs) in the north shore of Moorea, Society Islands, French Polynesia [31] and Amblygobius phalaena $(37,000-38,000$ eggs) in 
the coral reef at Sesoko Island, Okinawa, Japan [34], and similar to P. elongatus (2,600-29,400 eggs) in the Mekong Delta, Vietnam [9]. This

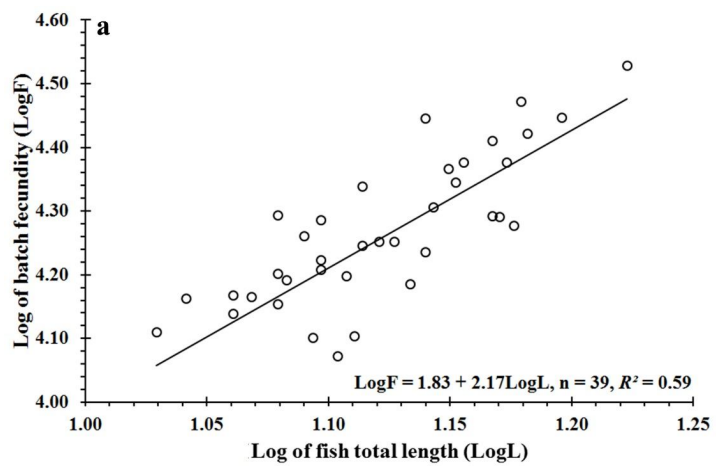

suggested that the different geographic regions lead to the different fecundity of $B$. boddarti in comparison with other gobiid species.

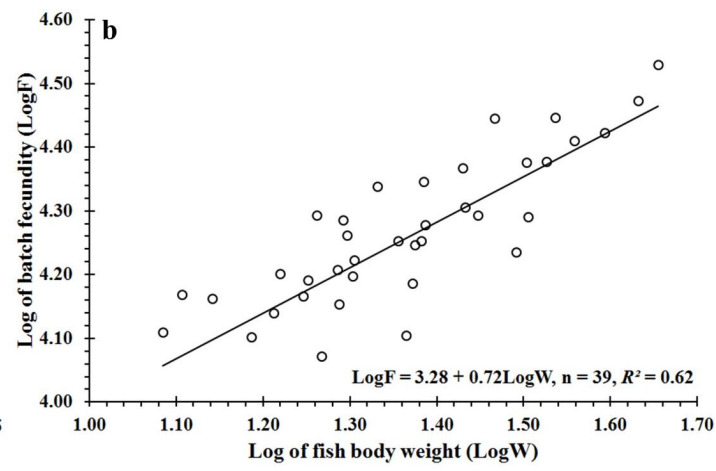

Figure 4. Relationship between fecundity ( $\log$ F) and (a) fish total length (logTL) and (b) body weight $(\log \mathrm{W})$ of $B$. boddarti

\section{CONCLUSION}

Boleophthalmus boddarti was a serial spawner shedding eggs over three months in the wet season. This fish reached $11.52 \mathrm{~cm}$ in total length and was high fecundity. The present study can provide a basis for further study on the culture and breeding of this mudskipper toward sustainable management. Knowing the size at maturity could allow fisherman and local authorities to set the appropriate size limit for fish catches and the fishing period in the dry season or late wet season to avoid catching a spawning fish population.

\section{REFERENCES}

1. Abrams P. A., Rowe, L., 1996. The effects of predation on the age and size of maturity of prey. Evolution, 50(3): 1052-1061.

2. Bagenal T. B., Braum, E., 1978. Eggs and early life history. In: Bagenal TB (ed) Methods for assessment of fish production in freshwater, Blackwell Scientific Publications, Oxford, United Kingdom pp. 165-201.

3. Bouchereau J., Quignard, J., Joyeux, J., Tomasini, J., 1993. Structure du stock des géniteurs de la population de Pomatoschistus microps (Kroyer, 1838) (Gobiidae), dans la lagune de Mauguio, France. Cybium, 17: 3-15.
4. Caputo V., Mesa, M. L., Candi, G., Cerioni, P. N., 2003. The reproductive biology of the crystal goby with a comparison to that of the transparent goby. J. Fish Biol., 62(2): 375-385.

5. Carleton H. M., Drury, R. A. B., Wallington, E., 1980. Carleton's Histological technique. Oxford University Press, London, United Kingdom.

6. Chandran R., Jaiswar, A. K., Jahageerdar, S., Poojary, N., Chakraborty, S., 2014. A study on reproductive biology of Boleophthalmus boddarti from Mumbai region. J. Indian Fish. Assoc., 41: 57-69.

7. Clayton D. A., 1993. Mudskippers. Oceanogr. Mar. Biol. Annu. Rev., 31: 507577.

8. Clayton D. A., Vaughan, T. C., 1986. Territorial acquisition in the mudskipper Boleophthalmus boddarti (Teleostei, Gobiidae) on the mudflats of Kuwait. J. Zool., 209(4): 501-519.

9. Tran Dac Dinh, 2008. Some aspects of biology and population dynamics of the goby Pseudapocryptes elongatus (Cuvier, 1816) in the Mekong Delta (Dissertation), Universiti Malaysia Teregganu, Malaysia.

10. Tran Dac Dinh, Shibukawa K., Nguyen Thanh Phuong, Ha Phuoc Hung, Tran Xuan 
Loi, Mai Viet Hieu, Utsugi K., 2013. Fishes of Mekong Delta, Vietnam. Can Tho University publisher, Can Tho.

11. Fontoura N. F., Braun, A. S., Milani, P. C. C., 2009. Estimating size at first maturity (L50) from Gonadossomatic Index (GSI) data. Neotrop. Ichthyol., 7(2): 217-222.

12. Fouda M. M., Hanna, M. Y., Fouda, F. M., 1993. Reproductive biology of a Red Sea goby, Silhouettea aegyptia, and a Mediterranean goby, Pomatoschistus marmoratus, in Lake Timsah, Suez Canal. J. Fish Biol., 43(1): 139-151.

13. Ip Y. K., Chew, S. F., Lim, L. L., Low, W. P., 1990. The mudskipper. Paper presented at the Essays In Zoology, National University of Singapore, National University of Singapore: 83-95.

14. King M., 2007. Fisheries Biology, Assessment and Management. Blackwell Publishing, Chicester, United Kingdom.

15. Komolafe O. O., Arawomo, G. A. O., 2007. Reproductive strategy of Oreochromis niloticus (Pisces: Cichlidae) in Opa reservoir, Ile-Ife, Nigeria. Rev. Biol. Trop., 55(2): 595-602.

16. Kovačić M., 2001. The biology of Roule's goby in the Kvarner area, northern Adriatic Sea. J. Fish Biol., 59(4): 795-809.

17. Kovačić M., 2007. Reproductive biology of the striped goby, Gobius vittatus (Gobiidae) in the northern Adriatic Sea. Sci. Mar., 71(1): 145-151.

18. Longhurst A. R., Pauly, D., 1987. Ecology of Tropical Oceans. Academic Press, San Diego, United States.

19. Macinnis A. J., Corkum, L. D., 2000. Fecundity and reproductive season of the round goby Neogobius melanostomus in the upper Detroit River. Trans. Am. Fish. Soc., 129(1): 136-144.

20. Mazzoldi C., Poltronieri, C., Rasotto, M. B., 2002. Egg size variability and mating system in the marbled goby Pomatoschistus marmoratus (Pisces: Gobiidae). Mar. Ecol. Prog. Ser., 233: 231-239.
21. Metin G., Ilkyaz, A. T., Soykan, O., Kinacigil, H. T., 2011. Age, growth and reproduction of four-spotted goby, Deltentosteus quadrimaculatus (Valenciennes, 1837), in İzmir Bay (central Aegean Sea). Turkish J. Zool., 35(5): 711716.

22. Miller P. J., 1984. The topology of gobioid fishes. In: Potts GW, RJ Wootton (eds) Fish reproduction: Strategies and Tactics, Academic Press, Orlando, London, United Kingdom pp. 119-153.

23. Murdy E. O., 1989. A taxonomic revision and cladistic analysis of the oxudercine gobies (Gobiidae, Oxudercinae). The Australian Museum, Sydney, Australia.

24. Trinh Kieu Nhien, Tran Dac Dinh, 2012. The status of capture fisheries and management of marine fishes in Soc Trang Province. Can Tho Univ. J. Sci., 24b: 46-55 (in Vietnamese with abstract in English).

25. Polgar G., Crosa, G., 2009. Multivariate characterisation of the habitats of seven species of Malayan mudskippers (Gobiidae: Oxudercinae). Mar Biol., 156(7): 14751486.

26. Dinh Minh Quang, 2014. A preliminery study on length-weight relationship of the mudskipper Boleophthalmus boddarti in Soc Trang. Tap chi Sinh hoc, 36(1): 88-92.

27. Dinh Minh Quang, 2015. Preliminary study on dietary composition, feeding activity and fullness index of Boleophthalmus boddarti in Mekong delta, Vietnam. Tap chi Sinh hoc, 37(2): 252-257.

28. Dinh Minh Quang, Nguyen Thi Tra Giang, Ngo Nha Lam Duy, Dang Hoang Dong, Lam Trung Hau, 2014. Burrow configuration and utilization of the bluespotted mudskipper Boleophthalmus boddarti caught in Soc Trang, Vietnam. Kasetsart Univ. Fish. Res. Bull., 38(2): 1-7.

29. Rainboth W. J., 1996. Fishes of the Cambodian Mekong. FAO, Roma, Italy.

30. Ravi V., 2013. Food and feeding habits of the mudskipper, Boleophthalmus boddarti 
(Pallas, 1770) from Pichavaram mangroves, southeast coast of India. Int. J. Mar. Sci., 3(12): 98-104.

31. Reavis R. H., 1997. The natural history of a monogamous coral-reef fish, Valenciennea strigata (Gobiidae): 2. behavior, mate fidelity and reproductive success. Environ. Biol. Fishes, 49(2): 247-257.

32. Riede K., 2004. The "Global register of migratory species" - first results of global GIS analysis. In: Werner D (ed) Biological resources and migration, Springer Berlin Heidelberg, pp. 211-218.

33. Silva M., Gordo, L., 1997. Age, growth and reproduction of the black goby, Gobius niger, from Obidos Lagoon, Portugal. Cah. Biol. Mar., 38: 175-180.

34. Takegaki T., 2000. Monogamous mating system and spawning cycle in the gobiid fish, Amblygobius phalaena (Gobiidae). Environ. Biol. Fishes, 59(1): 61-67.

35. Takita T., Agusnimar, Ali, A., 1999.
Distribution and habitat requirements of oxudercine gobies (Gobiidae: Oxudercinae) along the Straits of Malacca. Ichthyol. Res., 46(2): 131-138.

36. Teichert N., Valade, P., Fostier, A., Lagarde, R., Gaudin, P., 2014. Reproductive biology of an amphidromous goby, Sicyopterus lagocephalus, in La Réunion Island. Hydrobiologia, 726(1): 123-141.

37. Vesey G., Langford, T. E., 1985. The biology of the black goby, Gobius niger L. in an English south coast bay. J. Fish Biol., 27(4): 417-429.

38. Wootton R. J., 1990. Ecology of Teleost Fishes. Chapman and Hall, New York, United States.

39. Mai Dinh Yen, 1992. Identification of fresh water fishes of South Vietnam. Science and Technology publisher, Ha Noi (in Vietnamese).

40. Zar J. H., 1999. Biostatistical Analysis. Prentice Hall, New Jersey, United States.

\title{
SINH HỌC SINH SẢN CÁ BỐNG SAO Boleophthalmus boddarti Ở KHU VỰC BÃI BỒI TỈNH SÓC TRĂNG
}

\author{
Đinh Minh Quang ${ }^{1}$, Nguyễn Thị Trà Giang ${ }^{1}$, Nguyễn Thị Kiều Tiên ${ }^{2}$ \\ ${ }^{1}$ Trường Đại học Cần Thơ \\ ${ }^{2}$ Trường Trung học Phổ thông An Khánh
}

\section{TÓM TÁ́T}

Cá bống sao Boleophthalmus boddarti là một loài cá bùn phân bố rộng ở vùng bãi bồi của nhiều khu vực ở châu Á, nhưng đặc điểm sinh học của chúng còn ít được biết đến. Nghiên cứu này được thực hiện ở vùng Trần Đề, Sóc Trăng, Việt Nam từ tháng 3 năm 2013 đến tháng 2 năm 2014 để tìm hiểu chỉ số sinh học sinh sản của cá bống sao. Kết quả phân tích 360 mẫu cá (188 cá cái và 172 cá đực) cho thấy tỷ lệ giới tính của cá bống sao không khác biệt giữa mùa khô và mùa mưa. Loài này sinh sản vào mùa mưa, đẻ trứng nhiều lần trong suốt mùa sinh sản và tập trung chủ yếu vào 3 tháng chính của mùa này (tháng 8 đến tháng 10 ) bởi vì nhiều giai đoạn khác nhau của tế bào trứng được tìm thấy trong tiêu bản lát cắt ngang tuyến trứng chín (giai đoạn V). Cá đực có thể phóng tinh trùng suốt mùa sinh sản bởi nhiều giai đoạn phát triển khác nhau của tinh trùng được phát hiện trong tiêu bản lát cắt ngang tuyến tinh chín (giai đoạn $\mathrm{V}$ ) của loài này. Loài cá này đạt chiều dài thành thục đầu tiên là $11,52 \mathrm{~cm}$ và có sức sinh sản cao (9.800-33.800 trứng), điều này cho phép chúng có thể thích nghi tốt ở vùng nhiệt đới gió mùa. Kết quả nghiên cứu về đặc điểm sinh học sinh sản của cá bống sao như sự thích sinh sản của loài này ở khu vực nghiên cứu làm cơ sở khoa học trong việc quản lý bền vững ở khu vực bãi bồi ở tỉnh Sóc Trăng.

Tù khóa: Boleophthalmus boddarti, cá bùn, chiều dài thành thục đầu, sinh sản, sức sinh sản tiên.

Ngày nhận bài: 10-8-2015 